\title{
Absolute estimation of line length as a function of sex
}

\author{
RONALD T. VERRILLO \\ Institute for Sensory Research, Syracuse University, Syracuse, New York 13210
}

\begin{abstract}
The method of absolute magnitude estimation (AME) was used to determine if there were differences between men and women in the perceived magnitude of line length. It was shown that no difference exists either in the growth rate (slope) of the power function or in the absolute value of numbers assigned to represent the subjective length of lines.
\end{abstract}

Threshold sensitivities in men and women have been reported for hearing (Corso, 1963; Spoor, 1967), olfaction (Koelega, 1970, Köster, 1965; Le Magnen, 1953; Schneider, 1967), pain (Clark \& Mehl, 1971; Procacci, Zoppi, Maresca, \& Romano, 1974), and vibrotaction (Goff, Rosner, Detre, \& Kennard, 1965; Plumb \& Meigs, 1961; Steinberg \& Graber, 1963; Verrillo, 1979; Verrillo \& Ecker, 1977). Few studies, however, have been concerned with the influence of gender upon suprathreshold responses to sensory stimulation. Verrillo (1979) showed that women perceived the subjective intensity of vibrotactile stimuli to be greater than did men, but in a small group of subjects men and women did not differ in their estimations of line length.

Since the estimation of line length is one of the most stable and easily measured scaling metrics, it was decided to extend the pilot study of Verrillo (1979) to a larger number of subjects. In the present study, the subjective length of lines was measured in 26 men and 26 women using the method of absolute magnitude estimation (AME) (Hellman \& Zwislocki, 1961, 1963, 1964, 1968; Zwislocki \& Goodman, 1980).

\section{METHOD AND PROCEDURE}

Black, horizontal lines were projected upon a white screen at a viewing distance of $3.7 \mathrm{~m}$ from the seated subject. Viewing was in a large, well illuminated room (fluorescent, $50 \mathrm{fc}$ ), and the luminance of the lines was $25 \mathrm{fL}$ on a 50 -fL background. The physical lengths of the seven lines measured at the screen were $1.4,2.8,5.0,13.2,26.6,53.3$, and $132.5 \mathrm{~cm}$. They were presented in random order twice for each subject, with the restrictions that the first stimulus not be the shortest or the longest line and that lines of the same length not appear in succession. The geometric mean of the two estimates was taken at each line length.

AME was used. In this method, the subject is instructed to assign a number, without standard or modulus, to each line length such that the subjective magnitude of the number matches the subjective magnitude of the line. All subjects were tested individually. Twenty-six males and 26 females between the ages of 19 and 68 years were tested. All had normal or corrected vision.

This research was supported by Grant NS 09940 from the National Institutes of Health, U.S. Department of Health and Human Services.

\section{RESULTS AND DISCUSSION}

The geometric means of the two groups of subjects are shown in Figure 1 along with their standard-error bars. The linear regression lines for the two groups, computed by the method of least squares, were so close that they are represented in the figure by a single line. The slope value of the power function was .95 for each group.

Having established that the growth rate of subjective line length does not differ between men and women, the differences in absolute numbers used by the two groups were tested for significance. For this assessment, a student's $t$ test (two-tailed) was applied to the geometric means of all numerical estimates collapsed across

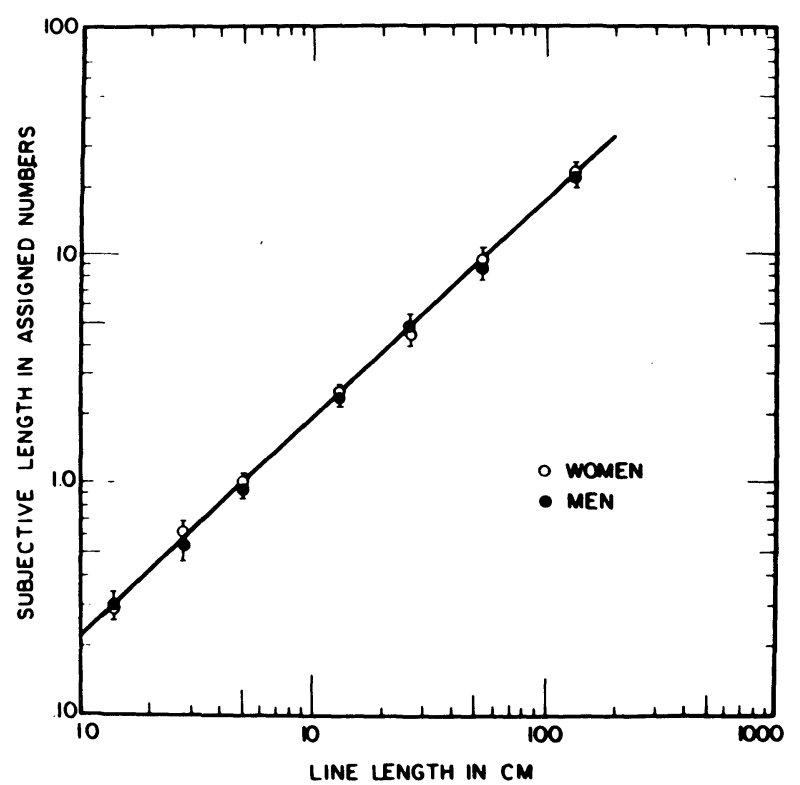

Figure 1. Geometric means with standard-error bars of the numbers assigned by 26 men $(\bullet)$ and 26 women $(\circ)$ to represent the subjective length of projected, horizontal lines. The estimates are plotted as a function of physical line length in centimeters. The slope of the power function, fitted by the method of least squares, was .95 for both groups. 
line lengths. This value was 2.37 for the women and 2.28 for the men. The value of $\mathrm{t}$ was $.28(\mathrm{df}=362)$, which is not significant at $\mathrm{p}>.50$.

It is apparent that the growth of the magnitude of perceived line length is independent of the sex of the viewer. The results also show that the numbers used by men and women to represent the perceived length of lines are not significantly different. Coupled with an earlier finding (Verrillo, 1981) that age beyond approximately 7 years is not a factor in line-length estimation, the present results confirm that estimation of line length is a convenient control for the use of numbers in magnitude-estimation experiments involving other sensory modalities.

\section{REFERENCES}

Clark, W. C., \& Meht, L. Thermal pain: A sensory decision theory analysis of the effect of age and sex on $\mathrm{d}^{\prime}$, various response criteria, and $50 \%$ pain threshold. Journal of Abnormal Psychology, 1971, 78, 202-212.

Corso, J. F. Age and sex differences in pure-tone thresholds. Archives of Otolaryngology, 1963, 77, 385-405.

Goff, G. D., Rosner, B. S., Detre, T., \& Kennard, D. Vibration perception in normal man and medical patients. Journal of Neurology, Neurosurgery, and Psychiatry, 1965, 28, 503-509.

Hellman, R. P., \& Zwislocki, J. Some factors affecting the estimation of loudness. Journal of the Acoustical Society of America, 1961, 33, 687-694.

Hellman, R. P., \& Zwislocki, J. Monaural loudness function at $1,000 \mathrm{cps}$ and interaural summation. Journal of the Acoustical Society of America, 1963, 35, 856-865.

Hellman, R. P., \& Zwislocki, J. Loudness function of a
$1,000 \mathrm{cps}$ tone in the presence of a masking noise. Journal of the Acoustical Society of America, 1964, 36, 1618-1627.

Hellman, R. P., \& Zwislocki, J. J. Loudness determination at low sound frequencies. Journal of the Acoustical Society of America, 1968, 43, 60-64.

Koelega, H. S. Extraversion, sex, arousal and olfactory sensitivity. Acta Psychologica, 1970, 34, 51-66.

Köste R, E. P. Olfactory sensitivity and the menstrual cycle. International Rhinology, 1965, 3, 57-64.

Le Magnen, J. L'olfaction: Le fonctionnement olfactif et son intervention dans les régulations psycho-physiologiques. Journal Physiologie Pathologie Général, 1953, 45, 285-326.

Plumb, C. S., \& Meigs, J. W. Human vibration perception: Part I. Vibration perception at different ages. Archives of General Psychiatry, 1961, 4, 611-614.

Procacci, P., Zoppi, M., Maresca, M., \& Romano, S. Studies on the pain threshold in man. In J. J. Bonica (Ed.), Advances in neurology (Vol. 4). International Symposium on Pain. New York: Raven, 1974.

Schneide R, R. A. The sense of smell in man. New England Journal of Medicine, 1967, 277, 299-303.

Spoor, A. Presbyacusis values in relation to noise induced hearing loss. International Audiology, 1967, 6, 48-57.

Steinberg, F. U., \& Graber, A. L. The effect of age and peripheral circulation on the perception of vibration. Archives of Physical Medicine and Rehabilitation, 1963, 44, 645-650.

VerriLlo, R. T. Comparison of vibrotactile threshold and suprathreshold responses in men and women. Perception \& Psychophysics, 1979, 26, 20-24.

Verrillo, R. T. Absolute estimation of line length in three age groups. Journal of Gerontology, 1981, 36, 625-627.

Verrillo, R. T., \& Ecker, A. D. Effects of root or nerve destruction on vibrotactile sensitivity in trigeminal neuralgia. Pain, 1977, 3, 239-255.

Zwislocki, J. J., \& Goodman, D. A. Absolute scaling of sensory magnitude. Perception \& Psychophysics, 1980, 28, 28-38.

(Received for publication May 3, 1982.) 